\title{
The Influence of 4G Mobile Value Added Services on Usage Intention: The Mediating Effect of Perceived Value of Smartphone and Phablet
}

\author{
Hsinkuang $\mathrm{Chi}^{1}$ \& Yanting Lai ${ }^{2}$ \\ ${ }^{1}$ Faculty of Department of Business Administration, Nanhua University, Chiayi, Taiwan \\ ${ }^{2}$ Department of Business Administration, Nanhua University, Chiayi, Taiwan \\ Correspondence: Hsinkuang Chi, Faculty of Department of Business Administration, Nanhua University, 55 Sec. \\ 1, Nau Hua Rd., Dalin, Chiayi 622, Taiwan, R.O.C. Tel: 886-5-272-1001 Ext. 50207. E-mail: \\ hkchi@mail.nhu.edu.tw
}

Received: October 20, 2015 Accepted: November 6, 2015 Online Published: November 30, 2015

doi:10.5539/ijms.v7n6p50 URL: http://dx.doi.org/10.5539/ijms.v7n6p50

\begin{abstract}
With the development of Phablet, as well as the coming of new age of $4 \mathrm{G}$ network, people pay more attention to the network quality and the market demand for network increases day by day. Telecommunications network service offers diversified products and service to satisfy different consumers' demands. Telecommunications service has gradually become the trend, but the issues about consumers' degree of cognitive involvement in using Smartphone or Phablet are the problems concerned by operators. In addition, the items supplied by the operators of telecommunications service will directly influence consumers' usage intention. Therefore, this study discussed whether the telecommunications mobile value added services will influence consumers' usage intention through the perceived value of Smartphone or Phablet. The research subjects were the users of general Smartphone. In total, 300 questionnaires were distributed, 240 questionnaires were retrieved and 224 questionnaires were valid. The research results show that (1) 4G mobile value added services have the significant positive influence on the perceived value of Smartphone; (2) 4G mobile value added services have the significant positive influence on usage intention; (3) Smartphone and Phablet have the mediating effect on 4G mobile value added services and usage intention. All the functions and value added services provided by Smartphone or Phablet play the key mediating effect. Thus, users will generate the sense of worth where acquisition utility is greater than expenditure cost, and they will generate the purchase intention and behavior towards this mobile phone product.
\end{abstract}

Keywords: 4G mobile value added services, perceived value of smartphone, perceived value of phablet, usage intention

\section{Introduction}

With the progress of science and technology, popularization of computers and the appearance of internet, the general public become more and more dependent on network multimedia, which plays the role of social channel between people, no longer merely providing a platform for the general public to inquire information on the internet. Therefore, more and more network multimedia platforms and network multimedia services appear one after another, such as Facebook, twitter, Google+, LINE, etc.

According to the investigation conducted by FIND in 2013, the annual growth speed of people's mobile internet popularity rate in Taiwan begins to break through units digit, rapidly rising with the annual growth rate of $10 \%$ and above, and the mobile internet popularity rate has reached $37.3 \%$, improving by $5.4 \%$ compared to the last year (2012). Additionally, with the joint push of telecommunications operators, the Smartphone develops at an alarming speed, almost presenting the growth by leaps and bounds. The mobile internet rate of joint and expanded public has reached $17 \%$. In addition, based on the main internet application behavior of the mobile internet groups in Taiwan, the proportion of using social network is the highest, respectively followed by information browsing, data searching, receiving and sending email, downloading mobile games, real-time communication and watching online films, short video or TV program (FIND, 2013).

With the appearance of Smartphone and the coming of $4 \mathrm{G}$ age with high-speed transmission, people's living habit and entertainment become more and more dependent on the convenience provided by Smartphone. It can 
be noticed all the time that Smartphone has been all around in our life, no matter whether the basic necessities or entertainment. However, it can be said that the appearance of Smartphone has thoroughly changed people's manner and habit in using network. Originally, people need to use the computer to surf the internet. All of a sudden, it changes into a status where people are able to surf the internet whenever and wherever possible merely with a Smartphone. Without the limit of space and time, people can really experience the $3 \mathrm{G}, 4 \mathrm{G}$ and telecommunications mobile value added, providing diversified products and service, bringing people the convenience and changes and satisfying different consumers' demands. However, the issues about consumers' degree of perceived value in using Smartphone or Phablet are still the problems concerned by operators, and the items supplied by the operators of telecommunications mobile value added services will directly influence consumers' usage intention towards Smartphone or Phablet.

Therefore, this study mainly aims to discuss whether the telecommunications $4 \mathrm{G}$ mobile value added services will influence consumers' usage intention through Smartphone or Phablet. The research objectives are as follows:

1) To understand consumers' usage status towards Smartphone or Phablet.

2) To discuss the influence of telecommunications $4 \mathrm{G}$ mobile value added on consumers' perceived value of Smartphone or Phablet.

3) To discuss the relationship and influence between telecommunications $4 \mathrm{G}$ mobile value added and usage intention.

4) To detect whether $4 \mathrm{G}$ mobile value added will influence usage intention through the perceived value of Smartphone or Phablet.

\section{Literature Review}

\subsection{Telecommunications Mobile Value Added}

The popularity of Smartphone products drives the explosion in information flow. Obviously, the existing 3G network system is insufficient for use, thus, $4 \mathrm{G}$ mobile communication technology LTE is born by taking advantage of such situation. It can be said to bring huge changes for the whole communication industry. The Taiwan's competent authorities NCC will release the certificate of 4G mobile broadband business at the end of this year, thus, Taiwan will also enter into the new age of $4 \mathrm{G}$ communication. On the other hand, as the marketing term of telecommunications operators, $4 \mathrm{G}$ refers to the 4 th wireless and networking services. $4 \mathrm{G}$ can provide a faster download speed and the better overall network quality, as well as improve the performance of online video streaming, video conference, online games and such applications. Consumers can also replace the DSL in their homes as $4 \mathrm{G}$ can be used both at home and in the open air, and $4 \mathrm{G}$ is also mobile broadband, therefore, the demands for $4 \mathrm{G}$ are considerable (Concord Securities Group, 2013).

In order to adapt to the rapid changes in technology and the tendency of market development, the telecommunications operators have always been actively constructing the high-speed mobile broadband network, evolving from the past $2 \mathrm{G}, 3 \mathrm{G}$ network to the current $4 \mathrm{G}$ LTE network and forming the dense mobile broadband communication network. On the other hand, the cloud platform is used to connect clients and services, deliver the information, contents and services required by clients, connect in series the content providers and service providers and form the perfect industry chain. According to the "key points of implementation on management and operation of mobile data communication business" issued by Ministry of Communications, the so-called mobile value added communication is defined as: "in a manner of using radio communication channel access, providing the data terminal equipment to the communication system in unfixed point or mobile status, for the use of transferring value added, voice or image" (Sun, 1999). The telecommunications classify mobile value added services into 4 types (1) mobile communication services: referring to the service through data transfer and communication with others, including short messages, MMS, e-mail, mobile instant message, PoC, videophone, etc; (2) mobile entertainment services: including the entertainment services in terms of pictures and tones download, Java game download, full-track MP3 download, mobile TV, etc; (3) mobile content services: including information services in terms of plain text news information, individual character query, meteorological information, etc; (4) mobile commercial services: including the relevant services in terms of mobile transfer, mobile ordering, mobile booking, mobile auction, etc. This expanded capability has enabled diversified forms of mobile services and commerce to become one of the most profitable markets with promising growth (Kim, Chan, \& Gopta, 2007).

With the rapid development of mobile value added communication technology and the innovation of Smartphone, mobile phone is no longer the tool for calls. Consumers hope to obtain more information and such demand 
development trend and market demand strength are the most important driving force of mobile value added services. Faced with such trend and challenge, the mobile value added services of telecommunications operators will provide more personalized and localized content services, including real-time audio and video news, weather, constellation, stock market, etc. Thus, clients can master the real-time information at any time. Meanwhile, the services also include calendar and contacts, personal bills, calling blacklist, pay the parking fees from bank account, path planning, personal positioning information, etc, as well as numerous practical living tools. Mobile value added services enable clients to easily obtain the information and service required through the smooth Smartphone interface and exquisite design, so as to stimulate the development of mobile internet and digital content industry, create the win-win development platform between industry and customers, satisfy users' demands and promote the development of value added services (Gu, Hung, \& Ho, 2010). In case of easy use of mobile value added, only a little time and effort are needed in searching for information. Thus, a kind of effective perception of mobile value added will be further generated (Chang \& Chen, 2008). Therefore, perceived value is one of the main determinative factors for usage attitude. Meanwhile, if the highly interactive characteristic is presented in the mobile value added tool, the perceived value and entertainment can be promoted, and the users' positive attitude and usage intention towards online communication tool will increase as well (Chang \& Chen, 2008). Therefore, mobile value added communication tool must establish highly interaction between users and phones. The tool will not only focus on task-oriented factors of developing online communication tool, it will also promote the entertainment-oriented factors. Thus, it can promote users' usage intention towards online communication tool (Chang \& Wang, 2009).

\subsection{The Perceived Value of Smartphone and Phablet}

The appearance of Smartphone has thoroughly changed people's life pattern. When you walk on the road, you can see the person bow his or her head to play the Smartphone anywhere. Moreover, the appearance of iPhone declares to the people the coming of Smartphone Age. Smartphone is like a set of small computer which is convenient for use and easy-to-carry. In the past, the touch-tone phone needs many different keys to compose a kind of executive program, while Smartphone has changed the previous method into the simple and rapid executive program, and different functions are independently unified into an individual where the function is clearly marked. Thus, only a touch can execute the program. The complex and unworkable method is thoroughly transformed into the operation method requiring no mental thought, and users are able to operate it at a glance. The functions of Smartphone become more and more powerful and widespread. In addition to the function of making and receiving calls, the functions of mobile communication, digital camera, wireless internet, document editing, bluetooth transmission, global positioning system, etc are also combined, which is exactly the biggest reason for the success of Smartphone.

Smartphone can display a consistent normal web page with the personal computer, and Smartphone can display the web page of mobile phone version which has the independent operating system and good use interface, owns the powerful software and hardware functions to drive the widespread application of each aspect and is able to conveniently and randomly install and delete applications. Smartphone has the super high-definition touchscreen, and the keyboard can be called at any time for touch handwriting and multitask operation can be conducted. Moreover, Smartphone also owns the powerful multimedia, email, web-surfing function and the application of global positioning system and can completely replace the traditional portable devices like PM3, MP4 and PDA. The Smartphone can deal with office affairs and other affairs in place of personal computer, maintain seamless connection all the time with the network, connect to network at any time and synchronize data with computer, laptop and other devices (Yang, 2009).

Nowadays, with the increasing popularity of Smartphone, on one hand, various sizes become more and more diversified to create differentiation, and on the other hand, it also brings operation convenience of large screen for users. The screen of 4.3 inches is especially representative. However, with the development of Phablet, many manufacturers pay close attention to the Phablet products mixed with Smartphone and tablet PC, such as HTC one max 5.9 inches, GALAXY Note 5.3 inches. Phablet is much larger in size and is the Smartphone much closer to tablet PC. In recent two years, the screen panel of global Smartphone continues to develop towards the larger size and higher resolution, and the shipments have set the high record again and again. More and more Smartphone manufacturers begin to develop towards the direction of over 5 inches and high resolution (Kyle, 2013). Concord Securities Group (2013) indicates that the shipment of Phablet has increased by $136 \%$ compared with the last year, from $25,600,000$ sets to $60,400,000$ sets, further reaching 1460 million sets in 2016. Many global Smartphone factories stand out from the elite, and it is expected to focus on large-sized Smartphone, quad-core communication products and 4G LTE. In 2014, it is not difficult to discover that LTE Smartphone will become one of indicators of the mainstream products in communication industry in the next few years (Wang, 
2013). Consumers can move to anywhere with Phablet, feeling reassuring. Better yet, ease of use, mobility and manipulative ability enable you to enjoy the pleasure of usage, and you can also use the uplifting method for sharing, play, creation, interaction and enjoying the sound-and-light entertainment.

The main characteristics of Phablet include quick start, longer time in usage, lightness, etc. DisplaySearch thinks that if Phablet can further intensify its appearance and performance, thus, the trend of replacing Smartphone will become more and more obvious (Wen, 2011). For instance, in the application processor, adopting multi-core processor; in the operation system, improving the stability; in the application, enlarging the quantity and quality of application; in the resolution, reaching the level of ultrahigh resolution. Even, Microsoft can install keyboard on the Phablet to satisfy people's demands for keyboard and to increase the demands of business persons. The users of tablet PC have the higher average satisfaction with Phablet than Smartphone (Kyle, 2012).

In the market environment with fierce competition, enterprises should try their best to satisfy consumers' demands and gradually use consumer orientation as the company's marketing strategy. Kevin Davis also indicates that in any sales, if you have known the consumers' inner thoughts, this business will have much bigger odds of success (Hsin (trans), 1996). Likewise, if the dealers of Smartphone and Phablet would like to understand the perceived value of Smartphone and Phablet users, they should inspect the value in consumers' mind and understand consumers' demands. Thus, they can definitely improve and increase consumers' perceived value, which is also one of the bases for decision making during the process of usage behavior of Smartphone or Phablet.

Krugman (1965) thinks that after consumers are subject to the stimulation of information clue, the generated perception in product quality cooperates with the consideration of sacrifice of monetary value to form the perceived value. In the end, the perceived value determines the purchase behavior. The perceived value is deemed as the balance between the "gains" and "pains" for one product (Dodds \& Monoroe, 1985; Chen \& Dubinsky, 2003; Kotler, 2003; Hellier, Geursen, Carr, \& Rickard, 2003; Monroe \& Krihnan, 1985). One overall utility evaluation is made through the choice between perceived price sacrifice of transaction utility theory and perceived benefits, and this overall utility evaluation is the perceived value (Thaler, 1985).

Smartphone or Phablet users' consideration for products is mainly influenced by their own perceived value, as perceived value is the personal demands, values, interests as well as the correlation degree towards this product perceived by users. When one article purchased has the highly correlation with consumers, the degree of perceived value will also be deepened. Consumers will evaluate carefully the gains and losses for the purchase, which is the Smartphone users' overall evaluation about whether Smartphone or Phablet products can satisfy their own demands. However, different degree of products' perceived value will influence consumers' usage intention, and the degree of consumers' perceived value will influence differently the usage intention effect (Zeithaml, 1988; Chi, Yeh, \& Tasi, 2011; Kotler, 2003; Hellier et al, 2003; Chi, Chang, \& Yu, 2008). Kan (2006) thinks that the positive improvement in users perceived quality for commodity will improve the perceived value for this commodity at the same time, and the usage intention will also be significantly positively increased and influenced. Zeithaml's (1988) research results show that consumers' purchase intention will be determined by the perceived value. The higher the consumers' perceived value is, the intention of using this product is bigger. All the functions and value added services provided by Smartphone or Phablet can make users generate the sense of worth where acquisition utility is greater than expenditure cost. Thus, users will generate the purchase intention and behavior towards this mobile phone product and the perceived value plays a key mediating or interference role in the mobile value added services (Chi et al, 2008; Chang, Wang, \& Yang, 2009). Therefore, perceived value has become the usage decision basis for Smartphone users.

\subsection{Usage Intention}

Usage intention falls into a kind of intention, which is classified as users' future intention by many researches during the verification. Blackwell, Miniard and Engel (2001) think that usage intention is psychologically a kind of decision-making process. When users have the demands, driven by the motivation of satisfying demands, users will search for the relevant information according to their own experience and external environment. When the information has reached the considerable accumulation, consumers will begin to evaluate and consider it. With the comparison and judgment, consumers will determine to use one commodity. Usage intention is a kind of behavior done by individuals when using one product as planned. The usage intention in the Technology Acceptance Model is to measure the users' intention strength in the process of using the innovative technology products (Fishbein \& Ajzen, 1975; Ajzen \& Fishbein, 1980; Ajzen, 1985), Wang (2014) show that both technology excellence and service experience are principal determinants of mobile value added service intention, then usage intention is generated; while mobile value added is the usage intention generated through 
telecommunications mobile value added services, in order to satisfy the demands of Smartphone and Phablet users.

Entering the $4 \mathrm{G}$ eras, a wider collection of mobile value added service offerings has been available that aims to serve either hedonic or utilitarian subscriber needs. Multimedia capability coupled with high band-width transmission in $4 \mathrm{G}$ eras, mobile value added service have evolved from communication centric services toward personal centric services serving both utilitarian and hedonic purposes of personal use (Ng \& Kwahk, 2010). Being able to differentiate by offering unique service experiences is crucial to the success of mobile value added service (Vargo, Robert, \& Lusch, 2008). A unique service experience is crucial because mobile service value is phenomenological determined, and it is service experience that connects the customer with the service provider during the service provision process (Wang, 2015)

Chi et al. (2011) point out that Smartphone users' support in technology and interaction in system quality will increase usage intention. In addition, there exists perceived value in consumers towards innovation products and consumers will have the expectation towards the expectation or operation of actual functions and quality, which will influence the usage intention (Chi, Yeh, \& Yang, 2009). The research of Ke (2002) shows that the way of promotion has the significant effect on consumers' perceived value, and promotion activities can be used to arouse consumers' purchase intention. That is to say, telecommunications operators can spread messages through promotion. When users use the mobile value added services, the value added services can be obtained through Smartphone or Phablet. When the value added services become closer to the users' acceptable scope, the perceived value and usage intention will also improve. You (2009) conducts the research on the governmental personnel's usage intention towards Thin Client cloud computing, the result shows that the usage intention is mainly influenced by their own relevant attitudes and perceived value control. When users' fluency and mastery towards Thin Client network computing are assisted by appropriate resources, users' usage intention towards Thin Client will be higher. To put it simply, the usage intention of Smartphone or Phablet products is the users' intention towards telecommunications mobile value added services and high-speed transmission. If users think it useful and helpful, and they can master and apply resource assistance, thus, the behavior of purchase and usage intention can be formed.

\section{Research Methodology}

\subsection{Research Framework}

The research framework for this study is shown as Figure 1, where mobile value added is independent variable, usage intention is dependent variable and perceived value is the intervening and moderator variable, discussing whether the mobile value added services and perceived value have the significant influence on usage intention.

$\mathrm{H} 4$

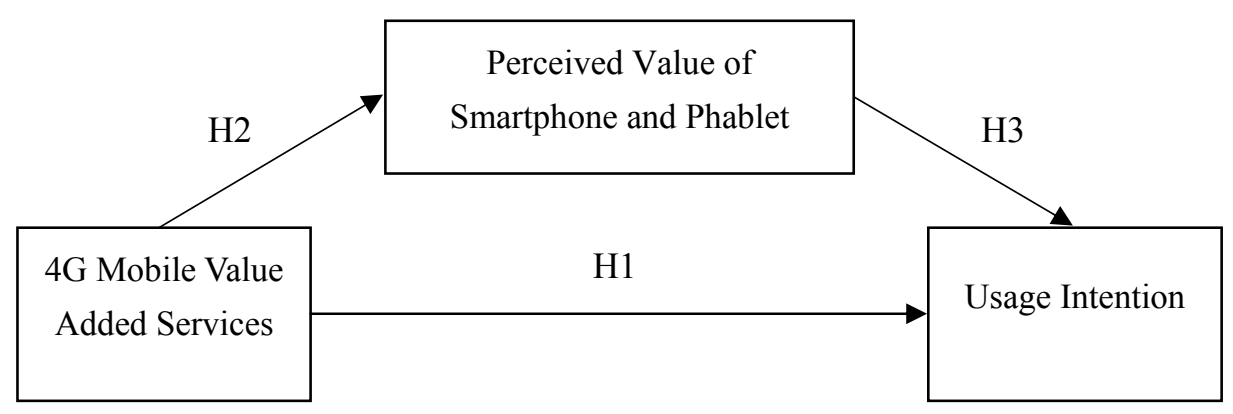

Figure 1. Research structure

\subsection{Research Hypotheses}

H1: 4G mobile value added services have the significant positive influence on usage intention.

H2: 4G mobile value added services have the significant positive influence on the perceived value of Smartphone.

H3: The perceived value of Smartphone has the significant positive influence on usage intention.

H4: The perceived value of Smartphone has the mediating effect on $4 \mathrm{G}$ mobile value added services and usage 
intention.

\subsection{Research Design and Samples}

This study aims to discuss the influence of telecommunications $4 \mathrm{G}$ mobile value added services on usage intention, using Smartphone as the mediating effect. The research subjects were the users of general Smartphone.

In the pretest of this study, 60 pretest questionnaires were distributed and 53 questionnaires were retrieved. The scale reliability analysis was conducted in pretest questionnaires. It can be known that the Cronbach's $\alpha$ coefficient of 4G mobile value added services, Smartphone, Phablet, and usage intention is respectively $.936, .905, .931$ and .868 , and the Cronbach's $\alpha$ coefficient of each dimension all reaches 0.7 and above. Therefore, this scale has the good reliability and the formal questionnaires are distributed.

This study adopted the convenience sampling method for sampling, and the questionnaires were distributed in schools, companies and hypermarkets. In total, 300 questionnaires were distributed in this study, 240 questionnaires were retrieved and the questionnaire collecting rate is $80 \%$. After removing the 16 invalid questionnaires with the uncertain and incomplete answers, there are totally 224 valid questionnaires and the collecting rate for valid questionnaire is $74.6 \%$.

\section{Research Results}

\subsection{Sample Characteristics Analysis}

In the samples of this study, there are 116 females (accounting for $51.8 \%$ of the total number of people) and 108 males (accounting for $48.2 \%$ of the total number of people); the age in 20 years old and below is the most, totally 77 persons (accounting for $34.4 \%$ of the total number of people), followed by the age $21 \sim 30$ years old, totally 52 persons (accounting for $23.2 \%$ of the total number of people). As for occupation, student is the most, totally 105 students (accounting for $46.9 \%$ of the total number of people), followed by soldiers, civil servants and teachers, totally 36 persons (accounting for $16.1 \%$ of the total number of people). The monthly income of NTD 20,000 and below is the most, totally 120 persons (accounting for $53.6 \%$ of the total number of people), followed by the monthly income of NTD 50,000 NTD 60,000, totally 30 persons (accounting for $13.4 \%$ of the total number of people). Work experience with 5 years and above is the most, totally 93 persons (accounting for $41.5 \%$ of the total number of people), and there are totally 61 persons without work experience (accounting for $27.2 \%$ of the total number of people). As usual, surfing the internet on the Smartphone products with 5 5.9 inches is the most, totally 129 persons (accounting for $57.6 \%$ of the total number of people), in which 46 persons are 20 years old and below (35.7\%), 25 persons are 21 30 years old (19.4\%), 29 persons are 31 40 years old (22.5\%), 18 persons are $41 \sim 50$ years old (13.9\%), 11 persons are 51 years old and above $(8.5 \%)$; followed by the Smartphone products with $4 \sim 4.9$ inches, totally 78 persons (accounting for $34.8 \%$ of the total number of people), in which 29 persons are 20 years old and below (37.2\%), 22 persons are $21 \sim 30$ years old $(28.2 \%), 13$ persons are $31 \sim 40$ years old $(16.7 \%), 6$ persons are $41 \sim 50$ years old $(7.7 \%), 8$ persons are 51 years old and above $(10.2 \%)$. When the people above are inquired whether they use the Phablet to make calls, the answer with "NO" is the most, totally 195 persons (accounting for $87.1 \%$ of the total number of people), in which, 69 persons are 20 years old and below (35.4\%), 46 persons are 21 30 years old (23.6\%), 38 persons are 31 40 years old (19.5\%), 25 persons are $41 \sim 50$ years old (12.8\%), 17 persons are 51 years old and above $(8.7 \%)$; totally, 29 persons will use Phablet to make calls (accounting for $12.9 \%$ of the total number of people), 8 persons are 20 years old and below (27.6\%), 6 persons are 21 30 years old (20.7\%), 4 persons are $31 \sim 40$ years old (13.8\%), 6 persons are $41 \sim 50$ years old (20.7\%), 5 persons are 51 years old and above (17.2\%); the favorable Smartphone size in 5 5.9 inches inquired is the most, totally 144 persons (accounting for $64.3 \%$ of the total number of people), in which, 51 persons are 20 years old and below (35.4\%), 27 persons are 21 30 years old (18.8\%), 31 persons are 31 40 years old (21.5\%), 23 persons are 41 50 years old (16\%), 12 persons are 51 years old and above (8.3\%), followed by the favorite Smartphone size in $4 \sim 4.9$ inches, totally 66 persons (accounting for $29.5 \%$ of the total number of people), in which 22 persons are 20 years old and below (33.3\%), 22 persons are 21 30 years old (33.3\%), 10 persons are $31 \sim 40$ years old (15.2\%), 4 persons are $41 \sim 50$ years old (6.1\%) and 8 persons are 51 years old and above (12.1\%).

\subsection{Reliability Analysis}

The reliability analysis of each variable for this study is shown in Table 1, the Cronbach's $\alpha$ of $4 \mathrm{G}$ mobile value added services is .926; the Cronbach's $\alpha$ of the perceived value of Smartphone is .917; the Cronbach's $\alpha$ of the perceived value of Phablet is .927; the Cronbach's $\alpha$ of usage intention is .870. The each research variable of this study reaches 0.7 and above, showing that each research variable of this study has the good internal consistency. 


\subsection{Pearson's Correlation Analysis}

Based on the correlation analysis of each variable, it can be known that $4 \mathrm{G}$ mobile value added services are significantly positively correlated with the variable of perceived value of Smartphone $(r=.560, p<0.1)$. 4G mobile value added services are significantly positively correlated with the variable of perceived value of Phablet $(\mathrm{r}=.318, \mathrm{p}<0.1) .4 \mathrm{G}$ mobile value added services are significantly positively correlated with the variable of usage intention $(\mathrm{r}=.451, \mathrm{p}<0.1)$. The perceived value of Smartphone is significantly positively correlated with the variable of perceived value of Phablet $(\mathrm{r}=.633, \mathrm{p}<0.1)$. The perceived value of Smartphone is significantly positively correlated with the variable of usage intention $(r=.640, p<0.1)$. The perceived value of Phablet is significantly positively correlated with the variable of usage intention $(r=.733, p<0.1)$ (See Table 1$)$.

Table 1. Results of Pearson's correlation analysis and reliability analysis

\begin{tabular}{llllllll}
\hline Variables & Mean & S.D & 1 & 2 & 3 & 4 & Cronbach's $\alpha$ \\
\hline 1. 4G mobile value added services & 5.1527 & 1.08957 & 1 & -- & -- & & .926 \\
2. Perceived value of Smartphone & 5.1911 & 1.13134 & $.560^{* *}$ & 1 & - & .917 \\
3. Pceived value of phablet & 4.6652 & 1.08848 & $.318^{* *}$ & $.633^{* *}$ & 1 & .927 \\
4. Usage intention & 4.9504 & .89952 & $.451^{* *}$ & $.640^{* *}$ & $.733^{* *}$ & 1 & .870 \\
\hline
\end{tabular}

Note. ${ }^{*} \mathrm{p}<.05 ; * * \mathrm{p}<.01 ; * * \mathrm{p}<.001$.

\subsection{Mediation Analysis}

The regression analysis of each variable for this study is shown in Table 2. According to the suggestions of Baron \& Kenny (1986), this study verified the mediating effect. Firstly, it can be known from Table 2 that model 1: $4 \mathrm{G}$ mobile value added services have the significant influence on the perceived value of Smartphone $(\beta=.560$, $\mathrm{P}<.001$ ), satisfying the condition that independent variable has the significant influence on intervening variable. Model 2: with the dependent variable of usage intention and the independent variable of $4 \mathrm{G}$ mobile value added services and the perceived value of Smartphone, it is found that $4 \mathrm{G}$ mobile value added services are significantly positively influence with usage intention $(\beta=.451, \mathrm{P}<.001)$, and the perceived value of Smartphone is also significantly positively influence with usage intention $(\beta=.640, \mathrm{P}<.001)$, thus satisfying the condition that independent variable and intervening variable have the significant influence on dependent variable. Model 3: the intervening variable placement (the perceived value of Smartphone) and independent variable (4G mobile value added) have the significant influence on the regression coefficient $(\beta=.135, \mathrm{P}<.05)$ of dependent variable (usage intention), and the standardized coefficient of independent variable decreases from .451 to .135 , showing the partial mediating effect. H4: it is true that the perceived value of Smartphone has the mediating effect on $4 \mathrm{G}$ mobile value added services and usage intention. Therefore, it proves that $4 \mathrm{G}$ mobile value added services influence the usage intention through the perceived value of Smartphone (See Table 2). Moreover, it can be known from Table 3 that model 1: 4G mobile value added service has the significant influence on the perceived value of Phablet $(\beta=.318, \mathrm{P}<.001)$, satisfying the condition that independent variable has the significant influence on intervening variable. Model 2: with the dependent variable of usage intention and the independent variable of 4G mobile value added services and the perceived value of Phablet, it is found that $4 \mathrm{G}$ mobile value added services are significantly positively influence with usage intention $(\beta=.451, \mathrm{P}<.001)$, and the perceived value of Phablet is also significantly positively influence with usage intention $(\beta=.733, \mathrm{P}<.001)$, thus satisfying the condition that intervening variable has the significant influence on dependent variable. Model 3: the intervening variable placement (the perceived value of Phablet) and independent variable ( $4 \mathrm{G}$ mobile value added) have the significant influence on the regression coefficient $(\beta=.243, \mathrm{P}<.05)$ of dependent variable (usage intention), and the standardized coefficient of independent variable decreases from .451 to .243 , showing the partial mediating effect. H4: it is true that the perceived value of Phablet has the mediating effect on $4 \mathrm{G}$ mobile value added services and usage intention. Therefore, it proves that $4 \mathrm{G}$ mobile value added services influence the usage intention through the perceived value of Phablet (See Table 3). 
Table 2. Results of mediation analysis

\begin{tabular}{|c|c|c|c|c|}
\hline \multirow{2}{*}{ Variables } & Model 1 & \multicolumn{2}{|l|}{ Model 2} & Model 3 \\
\hline & $\begin{array}{l}\text { Perceived value of } \\
\text { Smart phone }\end{array}$ & \multicolumn{2}{|c|}{ Usage Intention } & Usage Intention \\
\hline 4G mobile value added services & $.560 * * *$ & $.451 * * *$ & & $.135^{*}$ \\
\hline Perceived value of Smartphone & & & $.640 * * *$ & $.564 * * *$ \\
\hline $\mathrm{R}^{2}$ & .314 & .203 & .409 & .422 \\
\hline Adj. $R^{2}$ & .311 & .200 & .407 & .416 \\
\hline F-value & 101.521 & 56.706 & 153.756 & 80.585 \\
\hline
\end{tabular}

Note. $1 . * p<0.05, * * p<0.01, * * * p<0.001 ; \beta$ : unstandardized coefficient.

Table 3. Results of mediation analysis

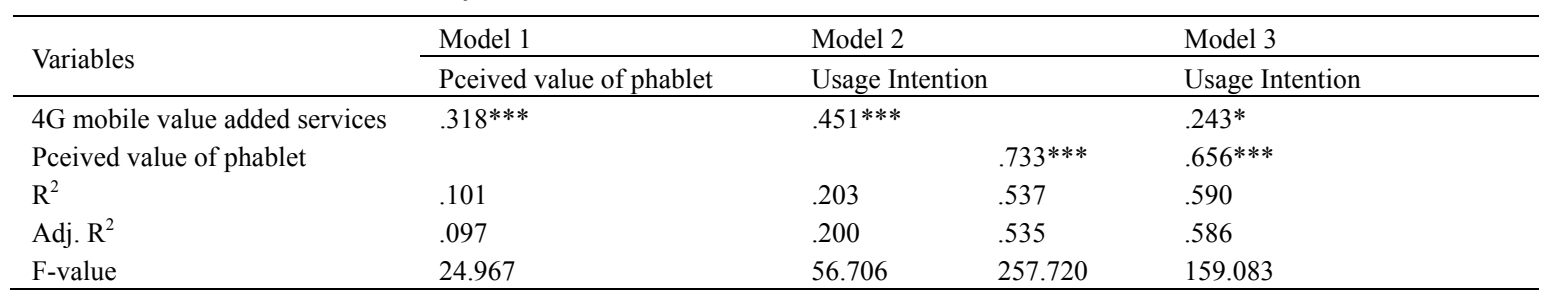

Note. $1 . * p<0.05, * * p<0.01, * * * p<0.001 ; \beta$ : unstandardized coefficient.

This study further considered the indirect effect by using the suggestions of Preacher and Hayes (2004), and conducted mediating verification by using CIs of Sobel test and boostrap approach. The Sobel analysis results of the perceived value of Smartphone on $4 \mathrm{G}$ mobile value added services and usage intention show that $\mathrm{Z}$ value is 6.7486 (being greater than $1.645 ; p<0.05)$ and the significance $(p=0.000)$ has reached the significant level, in which the mediating effect value is .2608 (See Table 4). The Sobel analysis results of the perceived value of Phablet on 4G mobile value added services and usage intention show that $\mathrm{Z}$ value is 4.7119 (being greater than $1.645 ; \mathrm{p}<0.05)$ and the significance $(\mathrm{p}=0.000)$ has reached the significant level, in which the mediating effect value is .1722 (See Table 5). The results also show that the perceived value of Phablet indeed has the mediating effect. Then, the result of BOOTSTRAP was used to verify Sobel test, the analysis result in Tables 4 and 5 shows that $\mathrm{CI}$ of $95 \% \sim 5 \%$ excludes 0 , showing that this mediating effect has reached the marginal significance. Therefore, this study inferred H4: it is true that the perceived value of Smartphone has the mediating effect on 4G mobile value added services and usage intention. H4: it is true that the perceived value of Phablet has the mediating effect on $4 \mathrm{G}$ mobile value added services and usage intention.

Table 4. Regression analysis of perceived value of smartphone between $4 \mathrm{G}$ mobile value added services and usage intention

\begin{tabular}{|c|c|c|c|c|c|c|}
\hline \multicolumn{7}{|c|}{ Direct effects and total effect } \\
\hline & & & \multirow{2}{*}{$\frac{B}{3724}$} & \multirow{2}{*}{$\begin{array}{c}\mathrm{SE} \\
.0495\end{array}$} & \multirow{2}{*}{$\frac{t}{7.5303}$} & \multirow{2}{*}{$\frac{\mathrm{p}}{.0000}$} \\
\hline IV I & $\overline{\mathrm{DV}}$ & & & & & \\
\hline IV & MV & & .5817 & .0577 & 10.0758 & .0000 \\
\hline MV & $\mathrm{DV}, \mathrm{DV}$ is cor & & .4484 & .0491 & 9.1331 & .0000 \\
\hline IV $\mathrm{I}$ & $\mathrm{DV}, \mathrm{MV}$ is cont & & .1116 & .0510 & 2.1884 & .0297 \\
\hline \multicolumn{7}{|c|}{ Indirect effect and significance using the normal distribution } \\
\hline & Value & SE & LL95\% CI & UL95\% CI & $\mathrm{z}$ & $\mathrm{p}$ \\
\hline Sobel & .2608 & .0386 & .1851 & .3366 & 6.7486 & .0000 \\
\hline \multicolumn{7}{|c|}{ Bootstrap results for indirect effect } \\
\hline & Value & SE & LL95\% CI & UL95\% CI & \multicolumn{2}{|c|}{ Mean } \\
\hline Effect & .2608 & .0479 & .1704 & .3597 & \multicolumn{2}{|c|}{.2598} \\
\hline
\end{tabular}

Notes. 1. IV: Independent variable (4G mobile value added services), DV: Dependent variable (usage intention), MV: Mediating variable (perceived value of smartphone). 2. N: 224, Number of bootstrap resamples: 5000, $\mathrm{LL}=$ lower limit, $\mathrm{CI}=$ confidence interval, $\mathrm{UL}=$ upper limit; 3. B= unstandardized coefficient. 
Table 5. Regression analysis of perceived value of phablet between $4 \mathrm{G}$ mobile value added services and usage intention

\begin{tabular}{|c|c|c|c|c|c|c|}
\hline \multicolumn{7}{|c|}{ Direct effects and total effect } \\
\hline & & & \multirow{2}{*}{$\frac{\mathrm{B}}{.3724}$} & \multirow{2}{*}{$\frac{\mathrm{SE}}{.0495}$} & \multirow{2}{*}{$\frac{\mathrm{t}}{7.5303}$} & \multirow{2}{*}{$\frac{\mathrm{p}}{.0000}$} \\
\hline IV & DV & & & & & \\
\hline & MV & & .3176 & .0636 & 4.9967 & .0000 \\
\hline & $\mathrm{DV}, \mathrm{DV}$ is co & & .5420 & .0375 & 14.4384 & .0000 \\
\hline IV & $\mathrm{DV}, \mathrm{MV}$ is con & & .2002 & .0375 & 5.3395 & .0343 \\
\hline \multicolumn{7}{|c|}{ Indirect effect and significance using the normal distribution } \\
\hline & Value & SE & LL95\% CI & UL95\% CI & $\mathrm{z}$ & $\mathrm{p}$ \\
\hline Sobe & .1722 & .0365 & .1005 & .2438 & 4.7119 & .0000 \\
\hline \multicolumn{7}{|c|}{ Bootstrap results for indirect effect } \\
\hline & Value & SE & LL95\% CI & UL95\% CI & \multicolumn{2}{|c|}{ Mean } \\
\hline Effec & .1722 & .0427 & .0942 & .2632 & \multicolumn{2}{|c|}{.1737} \\
\hline
\end{tabular}

Notes. 1. IV: Independent variable (4G mobile value added services), DV: Dependent variable (usage intention), MV: Mediating variable (perceived value of phablet). 2 . $\mathrm{N}: 224$, Number of bootstrap resamples: $5000, \mathrm{LL}=$ lower limit, $\mathrm{CI}=$ confidence interval, $\mathrm{UL}=$ upper limit; 3 . $\mathrm{B}=$ unstandardized coefficient.

\section{Conclusion and Suggestions}

\subsection{Conclusion}

Through the interface design of Smartphone or Phablet, the mobile value added services enable users to easily obtain the information and service required, generating a kind of effective perception in mobile value added. When the tool of mobile added value shows highly interactive characteristic, it can promote perceived value and entertainment and also increase users' positive attitude and usage intention towards online communication tools. Therefore, mobile value added can promote users' usage intention towards online communication tools.

Smartphone or Phablet both can display a consistent normal web page with the personal computer, having the good use interface. The keyboard can be called at any time for touch handwriting and multitask operation can be conducted. Moreover, Smartphone or Phablet also owns the powerful multimedia, email, web-surfing function and the application of global positioning system and can deal with office affairs and other affairs in place of personal computer, maintain the network connection and synchronize data processing with computer, laptop and other devices. Thus, Smartphone or Phablet both can satisfy the users' perceived value evaluation for demands. When the increased users' perceived value towards Smartphone or Phablet also has the significant positive influence on usage intention. However, all the functions and value added services provided by Smartphone or Phablet play the key mediating effect. Thus, users will generate the sense of worth where acquisition utility is greater than expenditure cost. Thus, users will generate the purchase intention and behavior for this mobile phone product. Meanwhile, this study has verified that the influence of the mobile value added of Smartphone on usage intention (mediating effect value is .2608) is greater than that of the mobile value added of Phablet on usage intention (mediating effect value is .1722). Moreover, $87.1 \%$ (195 persons) of users will not use Phablet to make calls, in which $61 \%$ (119 persons) of users think it inconvenient; $24 \%$ (47 persons) of users think it inaesthetic; $15 \%$ (29 persons) of users dislike it. The users' favorite Smartphone size and internet size used is 5 5.9 inches. Therefore, users' choice in Smartphone emphasizes convenience in use and carriage and beautiful appearance.

\subsection{Suggestions}

The dealer of Smartphone or Phablet are required to understand users' perceived value and inspect the value and demands in customers' mind, in this way, they can definitely improve users' perceived value towards Smartphone or Phablet. However, the functions and value added services of Smartphone or Phablet are required to make users generate the sense of worth where acquisition utility is greater than expenditure cost. Thus, the perceived value of Smartphone will play the key mediating effect on mobile value added services, making users generate the purchase intention and behavior.

\subsection{Suggestions for Future Studies}

In the sample selection, this study focused on the age 20 30 years old and students. Correspondently, the limit in inference will also increase. Therefore, it is suggested that the future researchers should further expand their research subjects to make the wider exploration. When samples answer and fill in the questionnaires, most of samples are influenced by the current environment, thus, there exist errors in the research results. Therefore, in 
addition to questionnaire survey, the research methods can also be supplemented by qualitative research and interview, so as to make the research results become more objective and complete.

\section{References}

Ajzen, I. (1985). From intentions to action: a theory of planned behavior. In J. Kuhland \& J. Beckman (Eds.), Action control: From cognitions to behavior (pp. 11-39). Heidelberg: Springer-Verlag. http://dx.doi.org/10.1007/978-3-642-69746-3_2

Ajzen, I., \& Fishbein, M. (1980). Understanding attitude and predicting social behavior. NJ: Prentice-Hall, Inc.

Blackwell, D. R., Miniard, P. W., \& Engel, J. F. (2001). Consumer Behavior (9th ed.). New York, NY: Harcourt, Inc.

Chang, H. H., \& Chen, S. W. (2008). The impact of customer interface quality, satisfaction and switching costs on e-loyalty: Internet experience as a moderator. Computers in Human Behavior, 24(6), 2927-2944. http://dx.doi.org/10.1016/j.chb.2008.04.014

Chang, H. H., \& Wang, I. C. (2009). An investigation of user communication behavior in computer mediated environments. BANYAN, 8(1).

Chang, H. H., Wang, Y. H., \& Yang, W. Y. (2009). The impact of e-service quality, customer satisfaction and loyalty on e-marketing: Moderating effect of perceived value. Total Quality Management \& Business Excellence, 20(4), 423-443. http://dx.doi.org/10.1080/14783360902781923

Chen, Z., \& Dubinsky, A. J. (2003). A Conceptual Model of Perceived Customer Value in E-commerce: A Preliminary Investigation, Psychology \& Marketing, 20(4), 323-347. http://dx.doi.org/10.1002/mar.10076

Chi, H. K., Yeh, H. R., \& Tsai, Y. C. (2011/ Feb.). The Influences of Perceived Value on Consumer Purchase Intention: The Moderating Effect of Advertising Endorser. Journal of International Management Studies, 6(1), 92-97. http://www.jimsjournal.org/pi.html

Chi, H. K., Yeh, H. R., \& Yang, Y. T. (2009). The Impact of Brand Awareness on Consumer Purchase Intention: The Mediating Effect of Perceived Quality and Brand Loyalty. Journal of International Management Studies, 4(1), 135-144. http://www.jimsjournal.org/pi.html

Chi, H. K., Yeh, H. R., \& Yang, Y. T. (2011). Applying Theory of Reasoned Action and Technology Acceptance Model to Investigate Purchase Behavior on Smartphone. Journal of International Management Studies, 6(3), 139-149.

Chi, H., Chang, M., \& Yu, C. (2008). Test of a Mediating Model Linking Service Quality and Behavior Intention-The Case of Mobile Value-Added Services. Commerce \& Management Quarterly, 5(4), 575-596.

Concord Securities Group. (2010). $4 G$ network, A hundred schools of thought contend. Retrieved from http://www.moneydj.com/KMDJ/Report/ReportViewer.aspx?a=fecde136-7f05-49e5-b203-0e63c362671b\#i xzz2o1AVraTc

Dodds, W. B., \& Monroe, K. B. (1985). The effect of brand and price information on subjective product evalutions. Advances in Consumer Research, 12(1), 85-90.

Fishbein, M., \& Ajzen, I. (1975). Belief, Attitude, Intention, and Behavior: An Introduction to Theory and Research. Reading, MA: Addison-Wesley. http://people.umass.edu/aizen/f\&a1975.html

Gu, X. W., Hung, C. F., \& Ho, Y. C. (2010). Attacking opportunities of action value-added on cloud services both of service and quality are the focus of development. Retrieved December 12, 2014, from Communication Components Magazine. http://www.2cm.com.tw/markettrend_content.asp?sn=1008130015

Hellier, P. K., Geursen, G. M., Carr, R. A., \& Rickard, J. A. (2003). Customer Repurchase Intention: A General Structural Equation Model. European Journal of Marketing, 37(11/12), 1762-1800. $\mathrm{http}: / / \mathrm{dx}$. doi.org/10.1108/03090560310495456

Kan, M. L. (2006). The Relationship among Perceived Price, Perceived Quality and Perceived Value to Purchase Intention-the Empirical Research of Digital-Technology Products (Unpublished master thesis). National Cheng Kung University, Tainan, Taiwan.

Ke, C. H. (2002). The Effects of Sales Promotion on Buyer"s Purchasing Intensions-the Moderating Effect for Product Category (Unpublished master thesis). Tunghai University, Taichung, Taiwan.

Kim, H. W., Chan, H. C., \& Gupta S. (2007/2). Value-based Adoption of Mobile Internet: An empirical investigation. Decision Support Systems, 43(1), 111-126. http://dx.doi.org/10.1016/j.dss.2005.05.009 
Kotler, P. (2003). Marketing Management (11th ed.). NJ: Prentice-Hall Inc.

Krugman, H. E. (1965). The Impact of Television Advertising Learning without Involvement. Public Opinion Quarterly, 29(3), 349-356. http://dx.doi.org/10.1086/267335

Kyle. (2012). There are more women who have Kindle Fire than men in the united states. Retrieved from http://iknow.stpi.narl.org.tw/post/Read.aspx?PostID=7327

Kyle. (2013). Smartphone panel pursuit of larger and higher resolution. Retrieved from http://iknow.stpi.narl.org.tw/post/Read.aspx?PostID $=8180$

Monroe, K. B., \& Krishnan, R. (1985). The Effect of Price on Subjective Product Evaluations. In J. Jacoby \& J. Olson (Eds.), Perceived Quality (pp. 209-232). Lexington, MA: Lexington Books.

Ng, E. H., \& Kwahk, K. Y. (2010). Examining the Determinants of Mobile Internet Service Continuance: a Customer Relationship Development Perspective. International Journal of Mobile Communications, 8(2), 210-229. http://dx.doi.org/10.1504/IJMC.2010.031448

Sun, S. C. (1999). A Study on the Trends of Mobile Data Communications (Unpublished master thesis). National Chiao Tung University, Hsinchu, Taiwan.

Thaler, R. (1985). Mental Accounting and Consumer Choice. Marketing Science, 4(3), 199-244. http://dx.doi.org/10.1287/mksc.4.3.199

Vargo, S. L., \& Lusch, R. F. (2008). Service-Dominant Logic: Continuing the Evolution. Journal of the Academy of Marketing Science, 36(1), 1-10. http://dx.doi.org/10.1007/s11747-007-0069-6

Wang, K. (2015). Determinants of Mobile Value-Added Service Continuance: The Mediating Role of Service Experience. Information \& Management, 52, 261-274. http://dx.doi.org/10.1016/j.im.2014.11.005

Wang, K. X. (2013). 4G LTE new era of telecommunications, mobile, Netcom three race. Retrieved from http://estock.marbo.com.tw/ASP/BOARD/esubject.asp?BoardID=3\&ID=6914169

Wen, P. C. F. (2011). 3 inches? 4 inches? 5 inches? Smartphone screen size more and more diverse. Retrieved from http://iknow.stpi.narl.org.tw/post/Read.aspx?PostID=5909

$\mathrm{Wu}, \mathrm{H} . \mathrm{J}$. (2013). The status of actions and wireless Internet access in Taiwan. Retrieved from http://www.find.org.tw/market_info.aspx?n_ID $=7183$

Xin, H. N. (1996). Grasp the mentality of the customer's purchase. Executive Master of Business Administration, (119), 110-119.

Yang, Y. T. (2009). The Development Trend Analysis of Smart Phone Industry (Unpublished master thesis). National Cheng Kung University, Tainan, Taiwan.

Yu, K. P. (2009). A Study on Use Intention of Thin Client in E-Government Environment (Unpublished master thesis). National Kaohsiung First University of Science and Technology, Kaohsiung, Taiwan.

Zeithaml, V. A. (1988). Consumer perceptions of price, quality, and value: A means-end model and synthesis of evidence. Journal of Marketing, 52(3), 2-22. http://dx.doi.org/10.2307/1251446

\section{Copyrights}

Copyright for this article is retained by the author(s), with first publication rights granted to the journal.

This is an open-access article distributed under the terms and conditions of the Creative Commons Attribution license (http://creativecommons.org/licenses/by/3.0/). 